the Roman interpreter of Anaxagoras; from the caricature of the method by Aristophanes in the "Clouds", by the experimental basis of Pythagorean mathematics, and by the Hippocratic physiology, "to observe the invisible by means of the visible".

This revolution in outlook on Nature was the counterpart and outcome of the contemporary society of Ionia, a great social experiment by a mixed "people without a past", superseding tribal society by reasoned constructions and processes. The two revolutions, intellectual and political, went hand in hand. The working of iron popularized craftsmanship, the alphabet popularized law and justice. "The men who built the cities of Ionia were a new type of men", to be compared with the men of the age of Francis Bacon, intent alike on a "history of rature constrained and vexed by the art and agency of man" and a new age in human history, to be controlled by the same "art and agency" bréaking down medieval dogma and prejudice.

Conversely, the premature decay of Greek science, after this bright beginning, accompanied the growth of industrial slavery, and the contempt for craftsmanship among free citizens, encouraged by fourthcentury philosophers: whereas medicine, which had become a menial art, remained in touch with the craftsman, and progressed.

Thus it was "practice, not mere observation" that lay at the basis of Greek science. Even Plato admitted at last, after decrying human "improvements on nature", that "those of the arts that do produce something serious are all those that blend their power with that of nature, like medicine, agriculture, and gymnastics"-a curious assortment. Man here, as elsewhere in Greek practice, co-operates with Nature. His knowledge of Nature and his power over her are but two aspects of the same thing; and this includes the social background, man's human environment. In Ionia, as in the revival of learning, "for the first time political power was in the hands of free men, who were also masters of productive techniques", and could realize that the creation of man's civilization rests in his own hands-a tremendous responsibility, for 'labour' in other periods also.

\section{FORMAL GENETICS OF MAN*}

$\mathrm{M}^{\mathrm{A}}$ AN has obvious diaadvantages as an object of genetical study. The advantages are that very large populations are available, and that many serological diffofences and congenital abnormalities have been intensively investigated.

Some characters are found to obey Mendel's laws with great exactitude. In others the deviations are such as to suggest the existence of a considerable selective mortality, perhaps pre-natal. In yet other cases the observations are biased because we only 'know that we are investigating the progeny of two heterozygotes when the family includes at least one recessive. Statistical methods which eliminate this bias were described.

Still more complex methods are needed for the detection and estimation of linkage. Several such cases have been detected with greater or less certainty, and the frequency of recombination between the loci of the genes for colour-blindness and hæmophilia is now estimated at $11 \pm 4$ per cent. If the

- Substance of the Croonian Lecture of the Royal Society delivered by Prof. J. B. S. Haldane, F.R.S., on November 7 . theory of partial sex-linkage be accepted, it is possible to make a provisional map of a segment of the human sex chromosome.

When a gene is sublethal, as are those for.hæmophilia and achondroplasic dwarfism, its elimination by natural selection is in approximate equilibrium with its appearance by mutation, and the frequency of the latter process can be estimated. The mutationrates at five human gene loci lie between $4 \times 10^{-5}$ and $4 \times 10^{-6}$ per locus per generation. These are the only estimates available for vertebrates. The rates per generation are rather higher than those in Drosophila, but those per day are so small that much, or even all, human mutation may be due to natural radiations and particles of high energy.

\section{ACQUISITIONS AT THE BRITISH MUSEUM (NATURAL HISTORY)}

$7 \mathrm{HE}$ following notes on recent acquisitions have been issued by the British Museum (Natural History); this material will not be shown yet in the galleries open to the public.

Zoological acquisitions of special interest include two specimens of the Kutch wild ass specially procured and presented to the Trustees by the Maharao of Kutch ; this animal is found in the Runn of Kutch, a desert waste in western India between Sind and the State of Kutch. Other additions to the Department of Zoology include 131 mammals from the Gold Coast, including some rare squirrels, presented by Mr. G. S. Cansdale; a collection of birds from Syria and Palestine made by Mr. J. G. Williams; 130 birds from Sierra Leone, containing one new species, presented by Dr. W. Serle; a pale grey variety of the red grouse from Aberdeenshire, presented by Capt. Keith Caldwell; two Komodo dragons, originally presented to the Zoological Society by the late Lord Moyne, who had obtained them from the Island of Flores; a minnow which had lived for twelve years in an aquarium; a valuable collection of a hundred slides of foraminifera purchased from Mr. A. Earland.

The Department of Entomology has received from Mr. Thornley an important collection of Cornish insects, comprising some 26,300 specimens, together with thirteen manuscript diaries and an extensive card index of records. Mr. Thornley is a well-known naturalist now in his ninetieth year, and for the last twenty years he has specialized on the insects of Cornwall. In his earlier years he played a prominent part in the encouragement of nature study in elementary schools. His collection of Cornish insects has already formed the basis of a number of scientific papers, and others are in course of preparation.

The Department of Geology has purchased a large series of sections of petrified fossil plants from the British Coal Measures made over the last fifty years by Mr. W. Hemingway of Derby.

The Department of Mineralogy received numerous gifts of specimens during the war period. Among these may be mentioned two beautiful examples of native gold from Southern Rhodesia : one from old West Mine, Umtali, presented by Mr. D. V. Burnett in 1941, and the other presented by Mr. Percy Tarbutt, after whom the mineral tarbuttite was named. A very large piece of dark amber which had been bought in Canton in 1860 was presented by Major 